\title{
A mode of training computer education talents based on the requirements of "both red and expert"--taking Sichuan agricultural university as an example
}

\author{
Ping Mao ${ }^{1}$ and $X i$ Zhang $^{2, *}$ \\ ${ }^{1}$ School of Marxism, Sichuan Agricultural University, Ya'an, 625014, China \\ ${ }^{2}$ College of Mechanical and Electrical Engineering, Sichuan Agricultural University, Ya'an, 625014, \\ China
}

Keywords: Both red and expert, Talent training, Mode, computer education.

\begin{abstract}
Both red and expert", is comrade Xi Jinping's expectation of contemporary youth and the fundamental pursuit of socialist education. In the practice of running a school, Sichuan Agricultural University always adheres to the principle of "both red and expert" and "comprehensive development". To cope with the challenge of informationization to computer education talents, Sichuan Agricultural University has effectively explored a computer education talent training mode characterized by "excellent political quality, solid basic theory of specialty, strong practical ability", which will be beneficial to the cultivation of the high-quality computer science talents in China of new period.
\end{abstract}

\section{Introduction}

Talent fostering is the primary issue of education. The fundamental mission of the China Socialist University is to cultivate generations of useful talents, who uphold the leadership of the Communist Party of China(CPC) and aspire to strive for the cause of socialism with Chinese characteristics.[1] On April 22, 2016, Comrade Xi Jinping sent a letter to congratulate the 105th anniversary celebration of Tsinghua University. He pointed out that as a banner of China's higher education, Tsinghua University has fostered a large number of academic masters and top talents in the past 105 years. Tsinghua University has formed tradition of patriotism, pursuit of excellence, "both red and expert" and comprehensive development in cultivating students.[2] "Both red and expert" means a person not only has political correctness, but also has superb professionalism. Here,"red" refers to supporting the leadership of the CPC, and having a higher ideological and political quality. "Expert" refers to firmly grasping of a wide range of professional knowledge,and becoming an expert in his field.

\footnotetext{
* Corresponding author: zhangxi2279@163.com
} 
Sichuan Agricultural University, a century-old university of "Project 211 "and "Double First-Class", always adhered to the principle of "both red and expert" in the long history. In response to the new requirements of informatization for computer education talents, Sichuan Agricultural University has explored a talent-training mode of "strong political quality, solid foundation of professional theory, strong practical ability", which will contribute to the cultivation of high-quality computer talents in the new period of the country.

\section{Conceptualize educational idea, highlight the ideological and political quality, cultivate the professional spirit}

\subsection{Conceptualize educational idea, highlight the ideological and political quality}

Education idea is not only the school's spirit, but also the starting point of students' growth. If colleges and universities do not have the appropriate idea, it is impossible to take effective measures to achieve their goals. Under the new situation of accelerating the pace of informatization and cybersecurity having become a key issue, Sichuan Agricultural University has conceptualized the education idea of "morality, legal thinking, innovation and development", which applies to the whole process of teaching and management.

In the actual operation, there are two ways to improve students' ideological and political quality. One is to strengthen the patriotism education of students through the main channel of ideological and political theory course and school history course. we successfully combine patriotism education with school history and "the spirit of Sichuan Agricultural University" to foster students' loyalty to the party and love for the motherland. The other is to emphasize students' Party construction work, make students go deep into society, understand the trend of information development, develop the sense of mission and responsibility, form a spirit of cooperation and innovation through the Party and League activities, Volunteer activities, social service etc. The monitoring data of talent training quality in the last five years shows that the students majoring in computer education have good ideological quality and politics as a whole, with an average of 94.7 percent of students submitting applications for joining the Party and 28.3 percent of graduating class party members.

\subsection{Adapt to the requirements of informatization, cultivate the professional spirit}

All over the world, cybersecurity is getting trickier and is spreading to the political, economic, cultural, social, ecological, military and other fields. Comrade Xi Jinping pointed out that "the network security and informatization are mutually reinforcing. Security is the premise of development, development is the guarantee of security, and security and development should be promoted simultaneously."[3] The opinions of the CPC Central Committee and the State Council "on Strengthening and Improving Ideological and Political Work in Colleges and Universities under the New Situation" emphasized that "it is necessary to strengthen students' awareness of the state, the rule of law, and the sense of social responsibility."[4]Therefore, the professional spirit cultivation must naturally cover three aspects.

The first one is strengthening law education. In the ideological and political lessons, students are organized to study the National Security Law of the People's Republic of China, the Law of the People's Republic of China on Guarding State Secrets, and Cybersecurity 
Law of the People's Republic of China. Through the Cybersecurity publicity activities, the students' legal knowledge, the rule of law spirit and the rule of law thinking can be cultivated, the good habits of learning the law, abiding by the law and using the law is formed, which is beneficial to the national information security and network security cause.

The second one is reinforcing the professional spirit cultivation. Students are organized to watch the films such as "Internet Age" and "Craftsmen of the Nation". Then seminars are be hold on "National Security in the Information Age", "Mission of the Internet Age" and "Craftsman's Spirit". When students learn and master the professional knowledge of information technology, they shouldn't merely be satisfied with technical learning. It is necessary to turn the enthusiasm of technology into the idea of serving the society and expanding the value of life, developing a pursuit of "excellence, patience, professional, devotion".

The third one is paying attention to educational spirit cultivation. In the process of running a school, Sichuan Agricultural University tried to makes students understand the essence of education and the basic qualities that a teacher must have. Therefore, "Pedagogy", "Educational Technology" and other courses are set in the talent training program. To be a teacher of computer science, he should integrate the ideological quality into professional skills, unify theoretical knowledge and practical ability, understand difference between the virtual world and the real world, and put ambition into concrete activities and become a good teacher.

\section{Focus on career development, underpin the professional basic theory}

According to information of CNNIC, by June 2019, the number of Internet users in China had reached 854 million, an increase of 25.98 million over the end of 2018, and the Internet usage rate had reached $61.2 \%$. [5] With the trend of computer more and more widely used, the university computer professional training has put forward higher requirements on students' practical ability .

\subsection{Meet the needs of the industry, constantly perfect the talent training program}

The talent-training mode is different from the traditional mode. In the past, computer major generally adopts 4 years' studying at school, or 3.5 years' studying at school and 0.5 years' graduation practice pattern. The new training mode adopts the " $3+1$ " pattern for application-oriented talent training, 3 years' of school studying and 1 year's of graduation practice. The curriculum will be appropriately moved forward so that all computer professional basic courses and professional core courses will be implemented reasonably within the first three years. In the last year, students will do their graduation practice and graduation design in the seventh semester and finish their graduation reports in the eighth semester.

The teaching system embody computer education major's characteristics. The curriculum is revised annually to keep the program in step with reality. In the practice teaching session, flexible curriculum, such as "comprehensive practice "I," comprehensive practice II"are set in the talent training program. These courses ensure that the content of teaching is highly aligned with the needs of the IT industry development, revealing the characteristics of keeping pace with the times.

The curriculum reflects the characteristics of the major. Computer education major is mainly aimed at cultivating vocational teachers. While students master computer theory, 
they also need to master the theoretical knowledge of education and teaching. Therefore, courses such as "Education", "Educational Psychology" and "Educational Technology" are included in the talent training program. In recent years, the monitoring data of talent cultivation quality and the investigation of the employer's return visit show that the proportion of graduates engaged in teaching work in various schools is about $38.7 \%$, and some of them have become the backbone of the teams.

\subsection{Emphasize the teaching process management, guarantee the quality of teaching}

The textbook is appropriate for the characteristics of the talent-training mode. The training object is undergraduate students, which is different from the vocational colleges. Students are not only need to have computer basic theory knowledge, but also have computer practical skills. Therefore, we choose the ordinary college computer undergraduate textbooks, rather than high vocational college textbooks, which ensures that students firmly grasp the basic theoretical knowledge.

The teaching method meets the needs of talent training.Because the student source of computer education is not as good as other majors,it is necessary to moderately lower difficulty degree. Through online and offline teaching ways, teachers and students can directly communicate and interact with each other. By multi-level and multi-dimensional teaching, it not only meets the basic needs of most students, but also meets the needs of some students with good foundation.

The teaching practice satisfies the goal of talent training. The computer education major aims at cultivating applied talents, so it pays more attention to the evaluation of practical ability. In the basic courses and core courses of computer education major, the ordinary performance score (including experiment and classroom practical teaching) accounts for more than $40 \%$ and the final exam score accounts for less than $60 \%$. Except the traditional form of curriculum assessment, each year, an evaluation meeting consisting of class representatives, college leaders, and professors are held to assess the students' practical performance and reward the outstanding candidates.

\section{Strengthen practice training, improve practical ability}

The combination of teaching, productive labor and social practice is the inevitable requirement of Marxist educational theory, and it is also a notable feature of socialist higher education with Chinese characteristics. Sichuan Agricultural University attaches great importance to the practice training, emphasizing "learning to apply" and "the unity of knowledge and practice", encouraging to transform the basic theory into practical teaching activities.

\subsection{Attach importance to practical training, strive to improve practical ability}

Practical training plays an irreplaceable role in cultivating students' comprehensive quality, and improving students' ability to analyze and solve problems.

Firstly, emphasize the construction of the practice teaching bases. Sichuan Agricultural University provides an important platform for improving students' practical ability through the combination of on-campus and off-campus resource. In on-campus resource, the laboratories such as computer laboratory, information system laboratory, automatic control laboratory, sensor and testing technology laboratory were integrated into a comprehensive multifunctional practice teaching platform . In off-campus resource, here are two ways: 
One is to sign contracts with vocational high schools and vocational colleges to establish practice teaching bases. The second is to sign a contract with off-campus IT enterprises, which effectively guarantee the implement of course training, graduation practice and other activities through school-enterprise joint training.

Secondly, augment the curriculum practice session. In the training program, each computer professional course arranges more than $1 / 3$ of the class hours as experimental teaching, and some professional core courses also set up a practical session of 1-2 weeks. By increasing the proportion of practical training, students' practical ability is improved.

Thirdly, sharpen the comprehensive training session. In the second and third year of the university, through the "bringing in" strategy, school and enterprises jointly carry out professional comprehensive training. Through computer project management, theoretical knowledge is applied to the whole process of management. Project training not only allows students to effectively use their professional knowledge, but also allows students to understand the needs of the society for talents, and gain experience in project management and teamwork.

Finally, stress graduation practice session. The main goal of computer education major is to train vocational teachers. So, the graduates not only need to meet the requirements of ordinary undergraduate graduates, but also meet the requirements of vocational and technical graduates. In the seventh semester, except the traditional graduation practice requirements, all students of this major are required to take part in a 20 -weeks internship. During the internship, the enterprise and the school shall jointly supervise the students' work.

\subsection{Pay attention to practice training management, intensify the examination of practical session}

Firstly, shift from the traditional college assessment to the school-enterprise joint assessment. In addition to offering courses such as "Education" and "Educational Psychology (practical teaching)" in the curriculum system, in the 7th semester, students also need to carry out 20 weeks of post internship in vocational colleges and complete the writing of internship report. The college is responsible for the construction and management of the post-training base. The head of the department and the person in charge of the base are responsible for the internship of the students. After the internship period, the school and the practice base jointly conduct a comprehensive assessment of the students' internship results.

Secondly, shift from a single result assessment to a comprehensive process-oriented assessment. Adopting the strategy of "bringing in and going out", the high-quality IT technical team and the teachers in the school are combined to form a training team. The professional skill training is carried out step by step in the second and third years to promote students to transform professional knowledge into professional skills.In the sixth semester, comprehensive multi-dimension training will be carried out according to the different interests of the students. In accordance with the requirements of corporate management and IT project management, students will be required to write training log, project progress report, etc. Finally, the project assessment committee will be formed by the school and enterprise supervisors to evaluate the work of each team, ultimately improve students' professional skills and employability.

\section{Conclusion}

Currently, the development of internet has posed many new challenges for the sovereignty, security and interests. To cope with the challenge, socialist universities need to cultivate 
computer talents with good ideological and political qualities and strong professional skills. The computer education talent training mode explored by Sichuan Agricultural University regards "both red and expert" as an important indicator, and adopted a series of measures to ensure the actual effect in practice. This mode has made positive contributions to the development of computer science and information technology talents in the new era of China.

This paper is funded by the China Scholarship Council (CSC) and is one of the research results of the author during his visiting to the University of Birmingham.

\section{References}

1. Zhang Shuo. Xi Jinping emphasized at the National Education Conference: Adhere to the development path of socialist education with Chinese characteristics, and train socialist builders and successors of moral, intellectual, artistic, and artistic development in an all-round way [N]. People's daily.2018_09_11:01.

2. $\mathrm{Xi}$ Jinping. $\mathrm{Xi}$ Jinping's congratulatory letter to the 105 th anniversary of the establishment of Tsinghua University [N]. People's Daily, 2016-04-22 ( 01) .

3. Xi Jinping. Speech at the Symposium on Cyber Security and Informatization [N]. People's Daily, 2016 - 04 - 26: 02.

4. Central Committee of the Communist Party of China, State Council. Opinions on strengthening and improving the ideological and political work of colleges and universities under the new situation [N]. People's Daily, 2017 - 02 - 28: 01.

5. The state Internet information office of the People's Republic of China, CNNIC released the 44th statistical report on the development of China's Internet network, www.cac.gov.cn/2019-08/30/c_1124939590.htm 